\title{
Serum $\operatorname{Ig} M$ in Diagnosis of Infection in the Newborn
}

\author{
S. A. HAIDER \\ From the Department of Paediatrics, Bolton District General Hospital, Bolton, Lancashire
}

\begin{abstract}
Haider, S. A. (1972). Archives of Disease in Childhood, 47, 382. Serum IgM in diagnosis of infection in the newborn. Serum IgM levels were determined at weekly intervals from birth in 100 normal low birthweight and 100 normal birthweight infants during the first 4 weeks of life. The dynamics of serum IgM was also studied in 36 newborn infants with different types of infection and in 19 infants with probable infection. The behaviour of serum IgM in the infants with systemic infection and also in those suffering from superficial infection with systemic symptoms was significantly different from the normal. Serum IgM rose within two days of appearance of symptoms and the rise persisted as long as the infection was 'active'. With the eradication of infection the IgM level tended to fall. This characteristic dynamic pattern of serum IgM may be of considerable help in the diagnosis of neonatal infection, especially the clinically inapparent and atypical varieties that may have serious sequelae later in life.
\end{abstract}

The diagnosis of infection in the early days of life is inherently difficult. During pregnancy asymptomatic infections in the mother may affect the fetus, which may be clinically inapparent in the neonate and the consequences of such an infection may not be detected even for years. Infections acquired by the neonates postnatally may pass undetected and could later be responsible for considerable morbidity and mortality.

Recent studies have shown the usefulness of raised IgM levels in the umbilical cord serum in the diagnosis of intrauterine infection of the newborn infants (Stiehm, Ammann, and Cherry, 1966; Jones and Tobin, 1969). It has also been suggested that IgM readings on the cord and neonatal sera may permit screening neonates for congenital infections (Alford, 1969). Alford and others (Alford et al., 1967) have demonstrated the role of serum immunoglobulin determinations in the diagnosis of neonatal infections.

\section{The Study}

A study of the behaviour of serum IgM was undertaken in newborn babies. This paper presents a part of the same study and examines the value of serum $\operatorname{IgM}$ in the diagnosis of infection in neonates.

Received 15 November 1971.

\section{Material and Method}

Studies were made on infants admitted to one unit of the Bolton District General Hospital. Into this unit were admitted all low birthweight babies born on the maternity block or outside, all the neonates requiring special care and treatment, and as there were 22 lying-in beds, a number of normal birthweight babies were also admitted because their mothers required hospitalization. A few cases were from the Paediatric Infectious Diseases Unit of the Hulton Hospital, Bolton, and the Special Care Nursery of the Moorgate General Hospital, Rotherham. The period of study was from February 1969 to August 1971.

The babies were examined on admission. An attempt was made to classify the neonates as full term, early-fordates, or small-for-dates; but among the low birthweight babies the number of those strictly premature or dysmature was small, and in the majority there were signs of both prematurity and dysmaturity. The neonates were, therefore, classified according to birthweight irrespective of the period of gestation; those weighing $2.5 \mathrm{~kg}$ or less as 'low birthweight' (LBW) and those weighing over $2.5 \mathrm{~kg}$ as 'normal birthweight' (NBW) infants. Babies with no clinical abnormality (excluding the birthweight) and no laboratory evidence of bacterial infection of urine or faeces were considered normal.

Urine (in plastic bags) and faeces were collected from every baby routinely at weekly intervals during their stay on the units concerned and examined for bacterial infection. A specimen of blood was also collected weekly for $\mathrm{Hb}$, haematocrit, leucocyte count, and IgM 
estimation. However, the routine weekly examination of blood was discontinued when readings from 100 NBW (50 female and 50 male) and 100 LBW (50 female and 50 male) normal babies were obtained. Thereafter the weekly blood tests were made only on those babies who had an abnormality, clinical or otherwise. Serum IgM estimation and leucocyte count were also performed within 24 hours of appearance of symptoms.

Conventional techniques were used for the common laboratory tests. Serum IgM estimations were made by radial diffusion technique (Mancini, Carbonara, and Heremans, 1965) using the antisera supplied by Hyland Laboratories, Los Angeles, California.

\section{Results}

No cases were selected which might have produced biased effects on the results. Behaviour of serum IgM during the neonatal period was studied in 340 babies ( 100 normal NBW, 100 normal LBW, 36 with established infection, 19 with probable infection, 6 with haemolytic disease of the newborn, 21 with neonatal jaundice syndrome, 17 with neonatal hypoglycaemia, 5 with neonatal hypocalcaemia, 13 with asphyxia neonatorum, 11 with idiopathic respiratory distress syndrome, 3 with intracranial haemorrhage, 5 with haemorrhagic disease of the newborn, 2 with Down's syndrome, 1 with trisomy 18 syndrome, and 1 with trisomy 13 syndrome). The purpose of this paper is to assess the value of serum IgM in the diagnosis of infection in newborn infants. What follows therefore is a report on the results of investigations of the 36 neonates who had no other clinical abnormality except infection of some sort. The normal infants have been included as control. The results of the study on other cases may be reported in another communication, but a brief remark relevant to the subject here will be made during discussion.

Normal NBW infants (Fig. 1 and 2). Of the first 100 normal NBW babies (50 female and 50 male) studied the IgM levels in 89 (46 female and 43 male) infants varied from 5 to $31 \mathrm{mg} / 100 \mathrm{ml}$ serum during the neonatal period. The dynamics of IgM showed a characteristic pattern-the levels rose serially with time since birth without showing a significant drop (shown by hatched area in Fig. 1 and 2). No significant difference was observed in the two sexes. In $11 \%$ (4 female and 7 male shown in dots and lines in Fig. 1 and 2) the IgM levels appeared to differ significantly from the 'normal' (89\%). However, on closer observation it was noted that in 7 of the 11 babies the IgM levels were higher yet the dynamic pattern of IgM was not different from the 'normal'. 76 (68 of the 89 and 8 of the 11) infants were followed for an

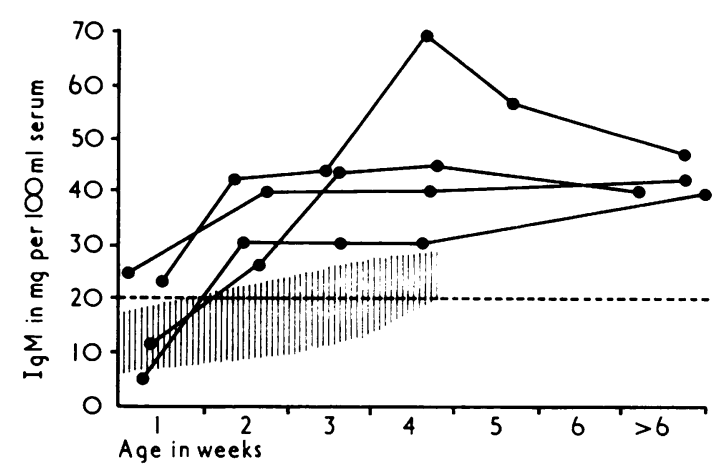

Fig. 1.- Serum IgM in 50 NBW normal female neonates. In 46 of the babies the IgM fell in the hatched area. 4 of the babies, shown in dots and lines, differed from the general pattern (see text).

average period of 8 months and were found to be thriving without any clinical abnormality.

Normal LBW infants (Fig. 3 and 4). In $92 \%$ (45 female and 47 male) of the normal LBW infants the IgM levels varied from 0 to $26 \mathrm{mg} / 100$ $\mathrm{ml}$ serum during the neonatal period. The dynamic pattern of IgM was similar to that of the 'normal' (shown in hatched area). There were no significant differences in the two sexes. In $8 \%$ ( 5 female and 3 male shown in dots and lines) of the neonates the $\operatorname{IgM}$ levels were significantly higher than 'normal', and in 5 of these the dynamic pattern was also characteristically different from the

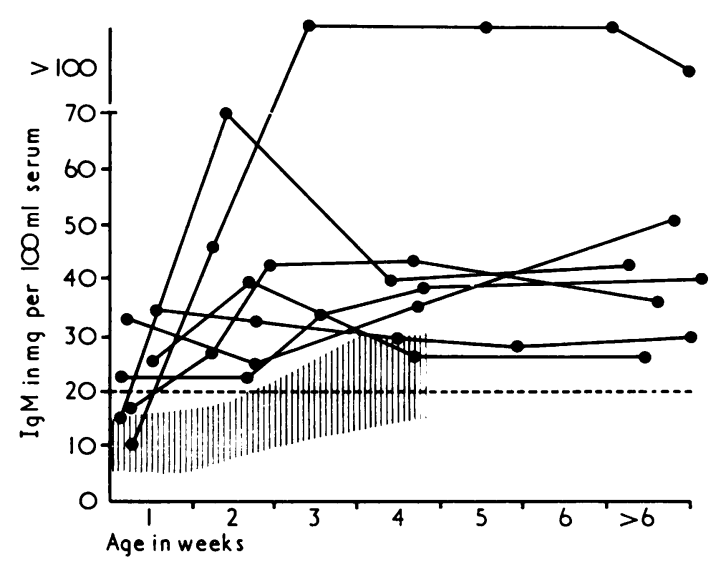

FIG. 2.-Serum IgM in $50 \mathrm{NBW}$ normal male neonates. In 43 of the babies the IgM fell in the hatched area. 7 of the babies, shown in dots and lines, differed from the general pattern (see text). 


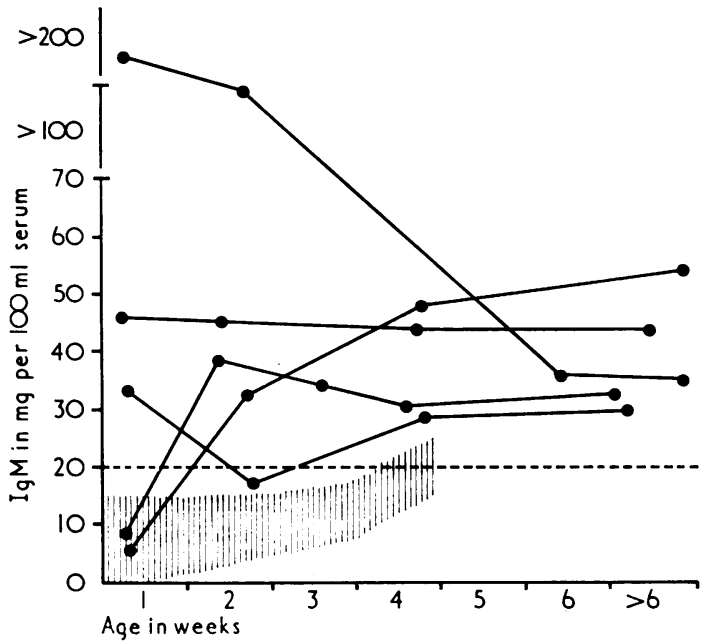

FIG. 3.- Serum IgM in $50 \mathrm{LBW}$ normal female neonates. In 45 of the babies the IgM fell in the hatched area. 5 of the babies, shown in dots and lines, differed from the general pattern.

'normal' - the IgM curves showed a fall after a rise. 87 infants ( 84 of the 92 and 3 of the 5) were followed for an average period of 11 months. Of the 84 infants followed, 1 died at the age of 28 weeks after an attack of gastroenteritis (no pathogenic organism isolated), and 3 showed retarded development. Of the 3 babies who had markedly raised serum $\operatorname{IgM}, 2$ were showing signs of cerebral palsy.

Neonates with offensive cord (Fig. 5 and Table I). The term omphalitis has been avoided

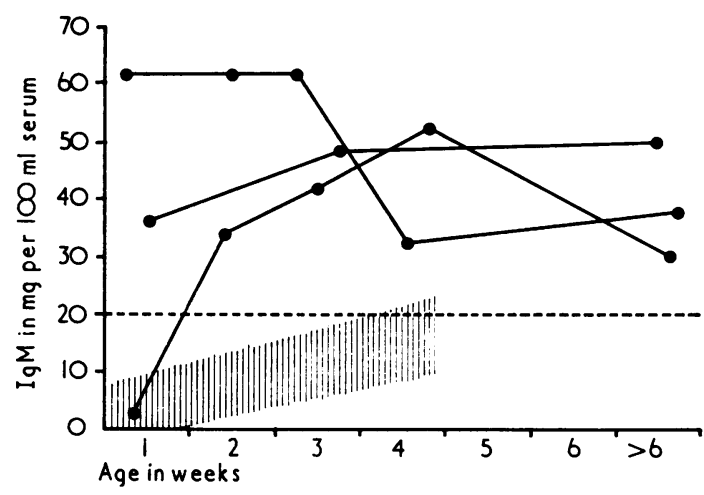

FIG. 4.-Serum IgM in $50 \mathrm{LBW}$ normal male neonates. In 47 of the babies the IgM fell in the hatched area. 3 of the babies, shown in dots and lines, differed from the general pattern.

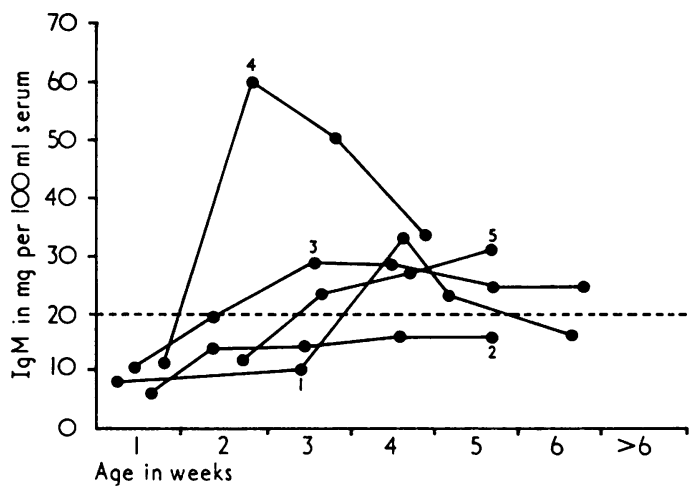

FIG. 5.-Serum IgM in the neonates with 'offensive cord' before and after treatment.

Summary of Relevant Clinical Data 全om

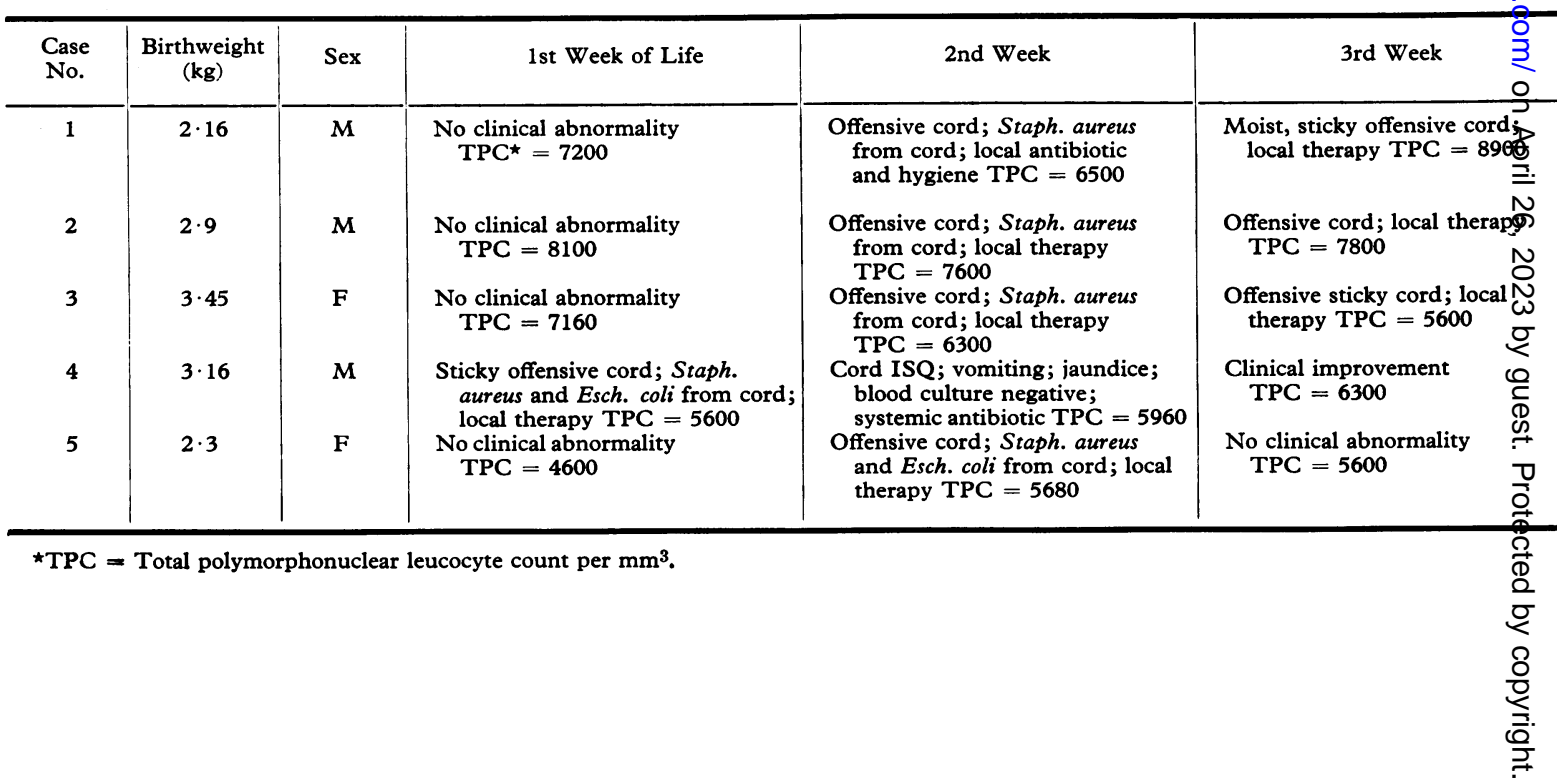


as the picture may not be considered complete for such a diagnosis in all 5 cases. In 3 of the 5 cases (Cases 2, 3, and 5) neither the levels nor the dynamic pattern of IgM was different from the 'normal'. In the other 2 (Cases 1 and 4) serum IgM rose to higher levels with the establishment of infection. This rise was followed by a significant fall in the IgM levels with the eradication of infection. It was also of interest to note that Cases 1 and 4 had systemic symptoms.

Neonates with oral thrush and breast abscess (Fig. 6 and Table II). Behaviour of serum IgM in the 3 newborn infants with oral thrush was not different from the 'normal' pattern. The infant with breast abscess (Case 9) had a significantly raised serum IgM which rose still higher till the abscess was drained. When the

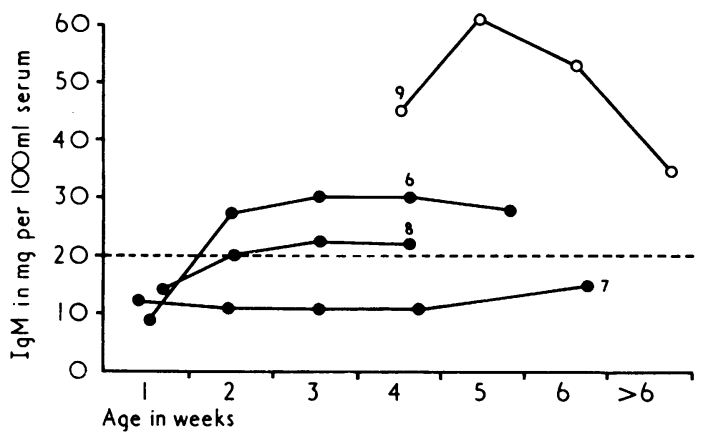

FIG. 6.-Serum IgM in the neonates with oral thrush (shown as dots) and breast abscess (shown as clear circles) before and after treatment.

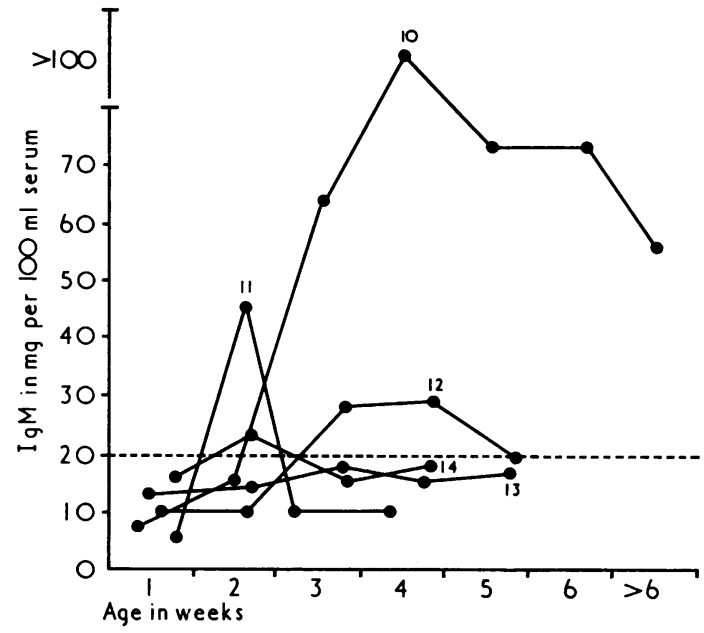

FIG. 7.-Serum IgM in the neonates with 'sticky eyes' before and after treatment.

infection was brought under control the IgM tended to fall.

Neonates with 'sticky eyes' (Fig. 7 and Table III). Serum IgM was markedly raised in 2 of the 5 infants (Cases 10 and 11). However, the dynamic pattern in 4 of the 5 may be considered different from the normal serum IgM rising with the infection and falling with its eradication.

Neonates with superficial skin infection (Fig. 8 and Table IV). Behaviour of serum IgM in $\mathbf{3}$ of $\mathbf{4}$ cases was not different from the 'normal'.

5 Neonates with 'Offensive Cord'

\begin{tabular}{|c|c|c|c|}
\hline 4th Week & 5th Week & 6th Week & Follow-up \\
\hline $\begin{array}{l}\text { Cord ISQ; slow to feed; } \\
\text { lethargic; blood culture } \\
\text { negative; systemic antibiotic } \\
\text { TPC }=8260 \\
\text { No clinical abnormality } \\
\text { TPC }=6980\end{array}$ & $\begin{array}{l}\text { Clinical improvement } \\
\text { TPC }=7900 \\
\text { No clinical abnormality } \\
\text { TPC }=5800\end{array}$ & $\begin{array}{l}\text { No clinical abnormality } \\
\text { TPC }=6500\end{array}$ & $\begin{array}{l}\text { Followed for } 7 \mathrm{mth} \text {; no clinical } \\
\text { abnormality } \\
\text { Not followed }\end{array}$ \\
\hline $\begin{array}{l}\text { No clinical abnormality } \\
\text { TPC }=6300\end{array}$ & No clinical abnormality & No clinical abnormality & Not followed \\
\hline $\begin{array}{l}\text { No clinical abnormality } \\
\text { TPC }=5800\end{array}$ & No clinical abnormality & & Not followed \\
\hline $\begin{array}{l}\text { No clinical abnormality } \\
\text { TPC }=5900\end{array}$ & No clinical abnormality & & $\begin{array}{l}\text { Followed for } 10 \mathrm{mth} \text {; no } \\
\text { clinical abnormality }\end{array}$ \\
\hline
\end{tabular}




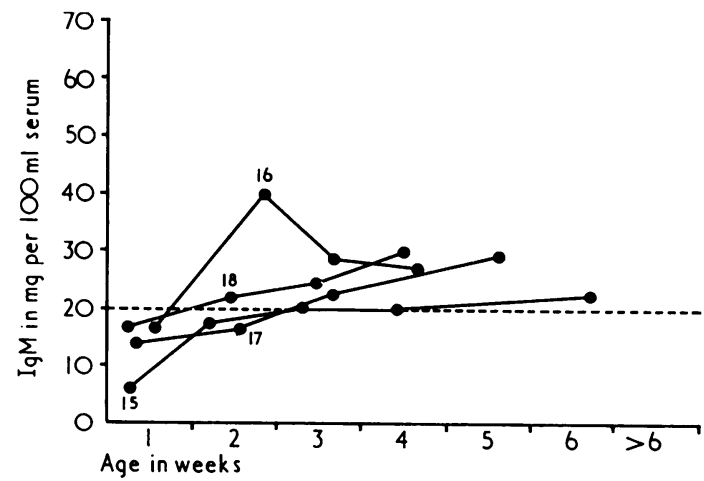

FIG. 8.-Serum IgM in the neonates with superficial skin infection before and after treatment.

In Case 16 the rise of IgM was higher and the level tended to fall with the control of infection.
Neonates with enteropathogenic Esch. coli infection (Fig. 9 and Table V). In 8 of the 9 cases serum IgM was markedly raised. The IgM rose serially till the infection was controlled. Eradication of the organism was followed by a significant fall in the IgM. In one case (22) however, the IgM tended to fall while Esch. coli 0126 were still being isolated from the faeces.

Neonates with infected urine (Fig. 10 and Table VI). It was realized that urinary infection should be diagnosed on clean-catch specimens, but the shortage of staff and time made it virtually impossible to get such specimens of urine. When the routine urine (bag specimen) examination showed at least 2 of the following 3 features, infection was suspected. (1) Pus cell count of 10 or more $/ \mathrm{mm}^{3}$ in male and 50 or more in female

Summary of Relevant Clinical Data from 3 Neoñate

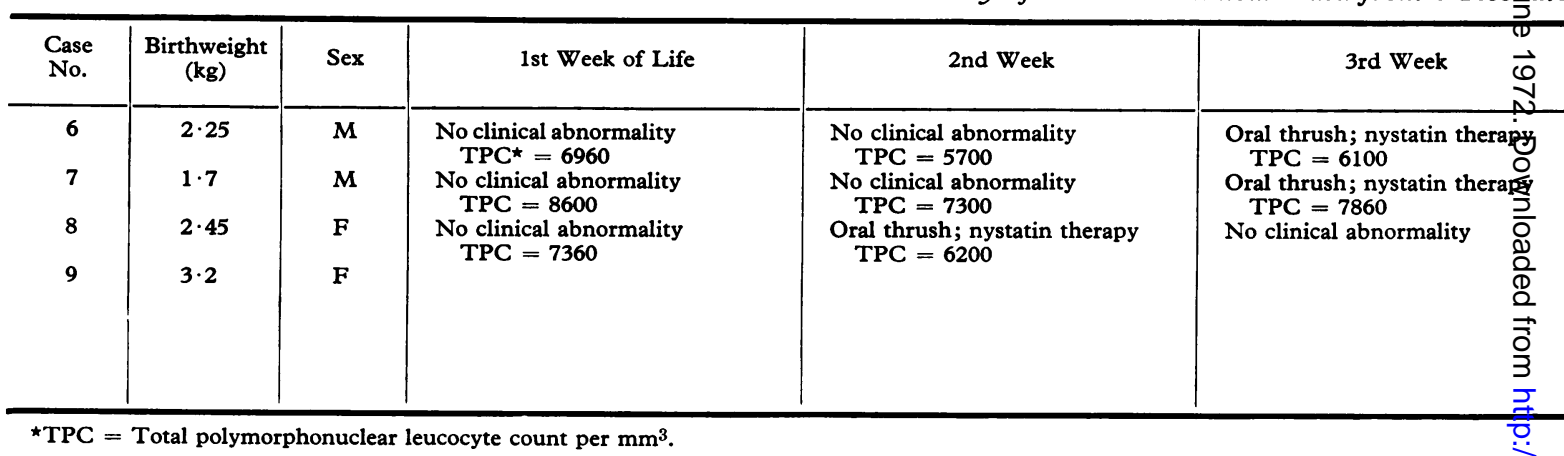

Summary of Relevant Clinical क् Datc

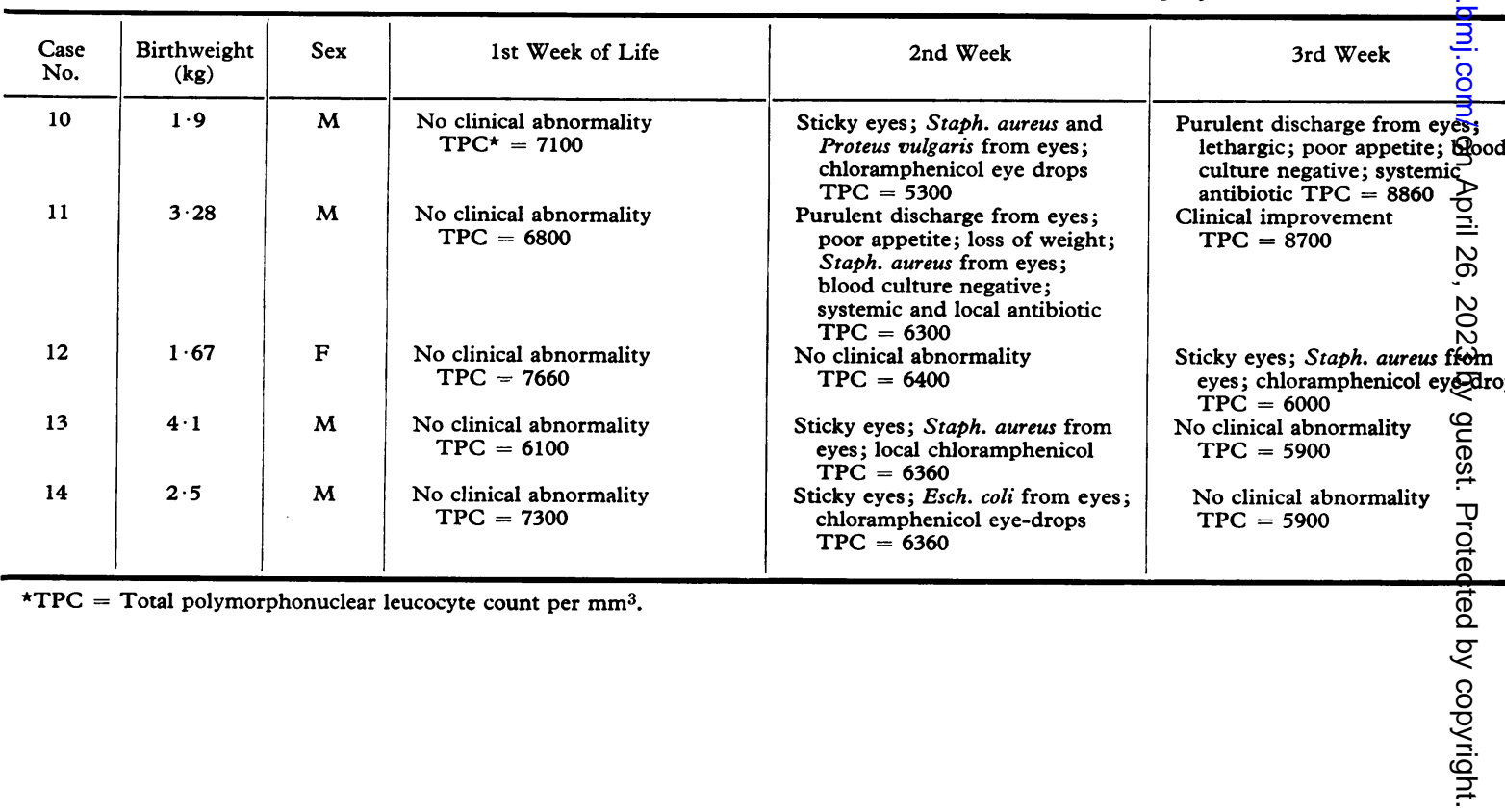




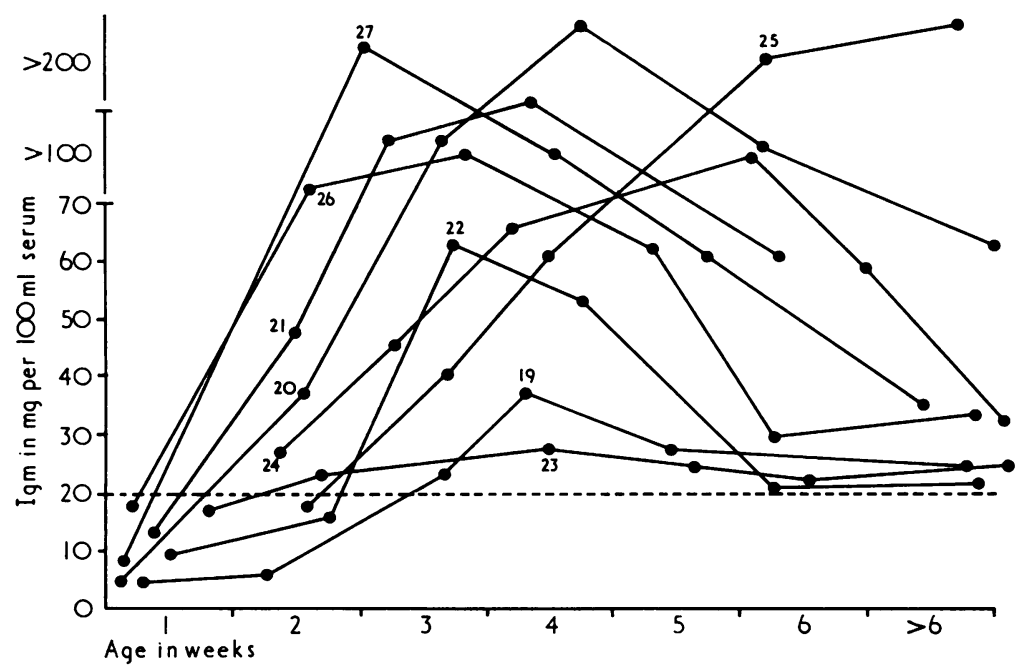

II

Fig. 9.-Serum IgM in the neonates with enteropathogenic Esch. coli infection before and after treatment. with Oral Thrush and One with Breast Abscess

\begin{tabular}{|c|c|c|c|}
\hline 4th Week & 5th Week & 6th Week & Follow-up \\
\hline $\begin{array}{l}\text { No clinical abnormality } \\
\text { TPC }=5300 \\
\text { No clinical abnormality } \\
\text { TPC }=7900\end{array}$ & $\begin{array}{l}\text { No clinical abnormality } \\
\text { No clinical abnormality } \\
\text { TPC }=7300\end{array}$ & No clinical abnormality & $\begin{array}{l}\text { Followed for } 10 \mathrm{mth} \text {; no clinical } \\
\text { abnormality } \\
\text { Followed for } 13 \mathrm{mth} \text {; no clinical } \\
\text { abnormality } \\
\text { Not followed }\end{array}$ \\
\hline $\begin{array}{l}\text { Admitted with nonfluctuant left } \\
\text { breast swelling, pyrexia, and } \\
\text { poor appetite; blood culture } \\
\text { negative; systemic antibiotic } \\
\text { TPC }=7600\end{array}$ & $\begin{array}{l}\text { Breast abscess incised and } \\
\text { drained; Staph. aureus from } \\
\text { pus; antibiotic continued } \\
\text { TPC }=8600\end{array}$ & $\begin{array}{l}\text { Clinical improvement; } \\
\text { antibiotic discontinued } \\
\text { TPC }=6360\end{array}$ & $\begin{array}{l}\text { Last IgM at } 8 \text { wk of age; no } \\
\text { clinical abnormality } \\
\text { TPC }=5160\end{array}$ \\
\hline
\end{tabular}

III

from 5 Neonates with 'Sticky Eyes'

\begin{tabular}{|c|c|c|c|}
\hline $\begin{array}{l}\text { Clinical improvement } \\
\text { TPC }=7600 \\
\text { No clinical abnormality } \\
\text { TPC }=6360\end{array}$ & $\begin{array}{l}\text { No clinical abnormality } \\
\text { TPC }=6360\end{array}$ & $\begin{array}{l}\text { No clinical abnormality } \\
\text { TPC }=5860\end{array}$ & $\begin{array}{l}\text { Last IgM at } 12 \text { wk of age; } \\
\text { followed for } 6 \text { mth; no } \\
\text { clinical abnormality } \\
\text { Not followed }\end{array}$ \\
\hline $\begin{array}{l}\text { No clinical abnormality } \\
\text { TPC }=5200 \\
\text { No clinical abnormality } \\
\text { TPC }=5900\end{array}$ & $\begin{array}{l}\text { No clinical abnormality } \\
\text { TPC }=5600\end{array}$ & & $\begin{array}{l}\text { Followed for } 11 \mathrm{mth} \text {; no } \\
\text { clinical abnormality } \\
\text { Not followed } \\
\text { Not followed }\end{array}$ \\
\hline
\end{tabular}


Summary of Relevant Clinical Data $\ddot{\text { fron }}$

\begin{tabular}{|c|c|c|c|c|}
\hline $\begin{array}{l}\text { Case } \\
\text { No. }\end{array}$ & $\begin{array}{l}\text { Birthweight } \\
\text { (kg) }\end{array}$ & Sex & 1st Week of Life & 2nd Week \\
\hline 15 & $1 \cdot 8$ & $\mathbf{M}$ & $\begin{array}{l}\text { No clinical abnormality } \\
\text { TPC }^{\star}=6900\end{array}$ & $\begin{array}{l}6 \text { pustules in axilla; Staph. } \\
\text { aureus from pustule; local } \\
\text { therapy TPC }=6300\end{array}$ \\
\hline 16 & $2 \cdot 95$ & $\mathbf{M}$ & $\begin{array}{l}\text { No clinical abnormality } \\
\text { TPC }=6100\end{array}$ & $\begin{array}{l}\text { Pustular eruption axillary and } \\
\text { cervical region; pyrexia; poor } \\
\text { appetite; loss of weight; } \\
\text { Staph. aureus from pustules; } \\
\text { blood culture negative; } \\
\text { systemic and local antibiotic } \\
\text { TPC }=7300\end{array}$ \\
\hline 17 & $2 \cdot 25$ & $\mathbf{M}$ & $\begin{array}{l}\text { No clinical abnormality } \\
\mathrm{TPC}=5900\end{array}$ & $\begin{array}{l}\text { No clinical abnormality } \\
\mathrm{TPC}=5600\end{array}$ \\
\hline 18 & $2 \cdot 68$ & $\mathbf{F}$ & $\begin{array}{l}\text { No clinical abnormality } \\
\mathrm{TPC}=6300\end{array}$ & $\begin{array}{l}\text { Multiple pustules; Staph. aureus } \\
\text { from pustule; TPC }=5700\end{array}$ \\
\hline
\end{tabular}

${ }^{\star} \mathrm{TPC}=$ Total polymorphonuclear leucocyte count per $\mathbf{m m}^{3}$.

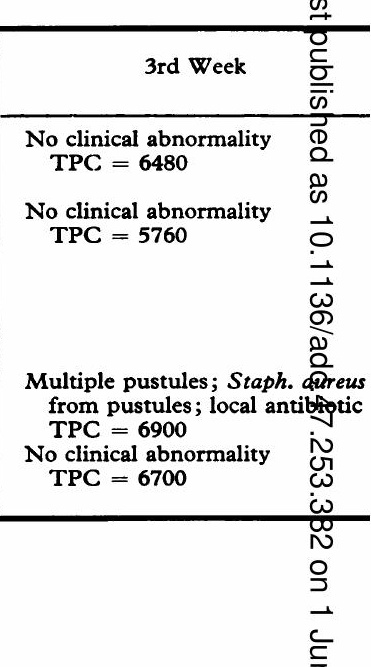

TAB̆

Summary of Relevant Clinical Data $\underset{\mathrm{N}}{\mathrm{S}}$

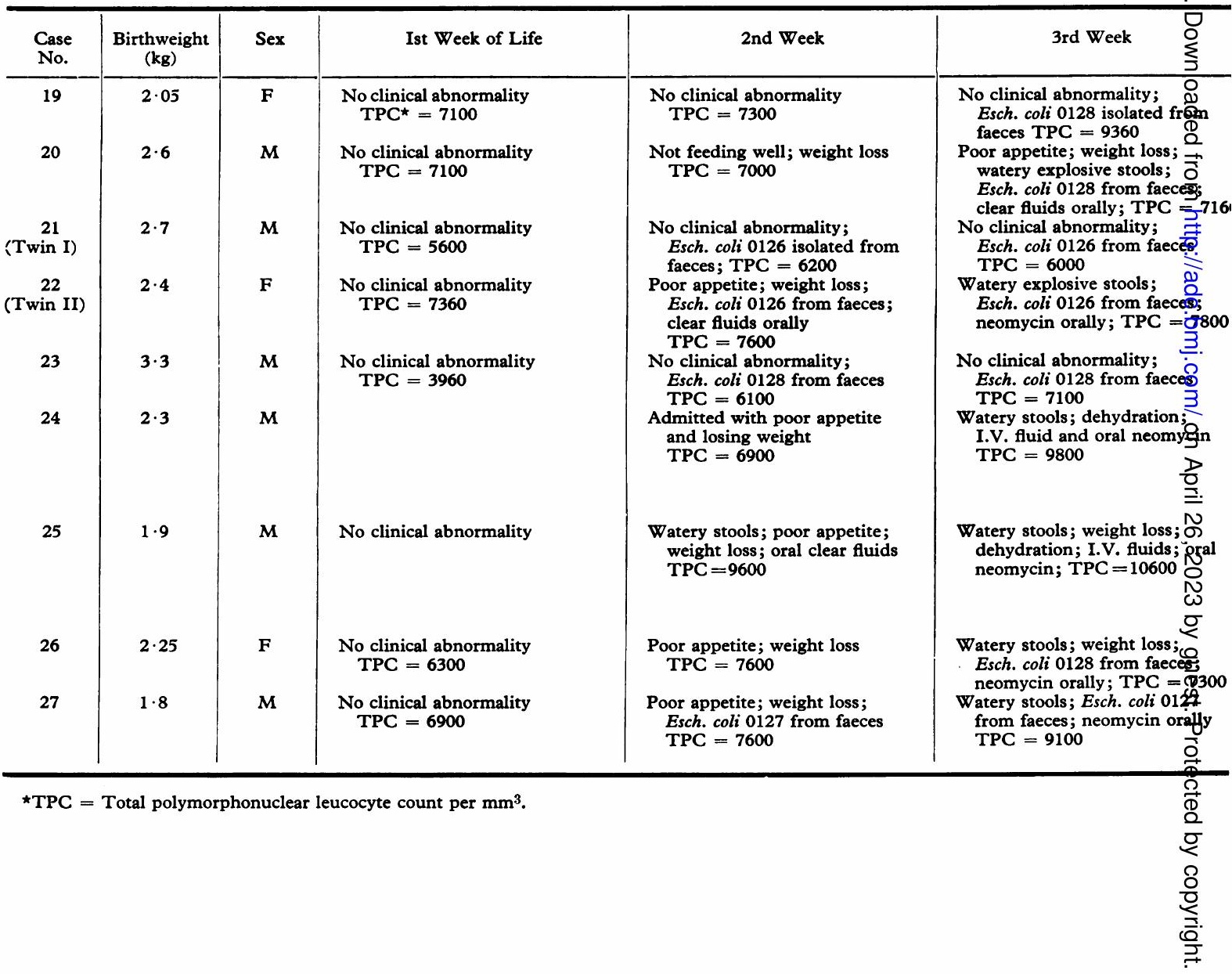




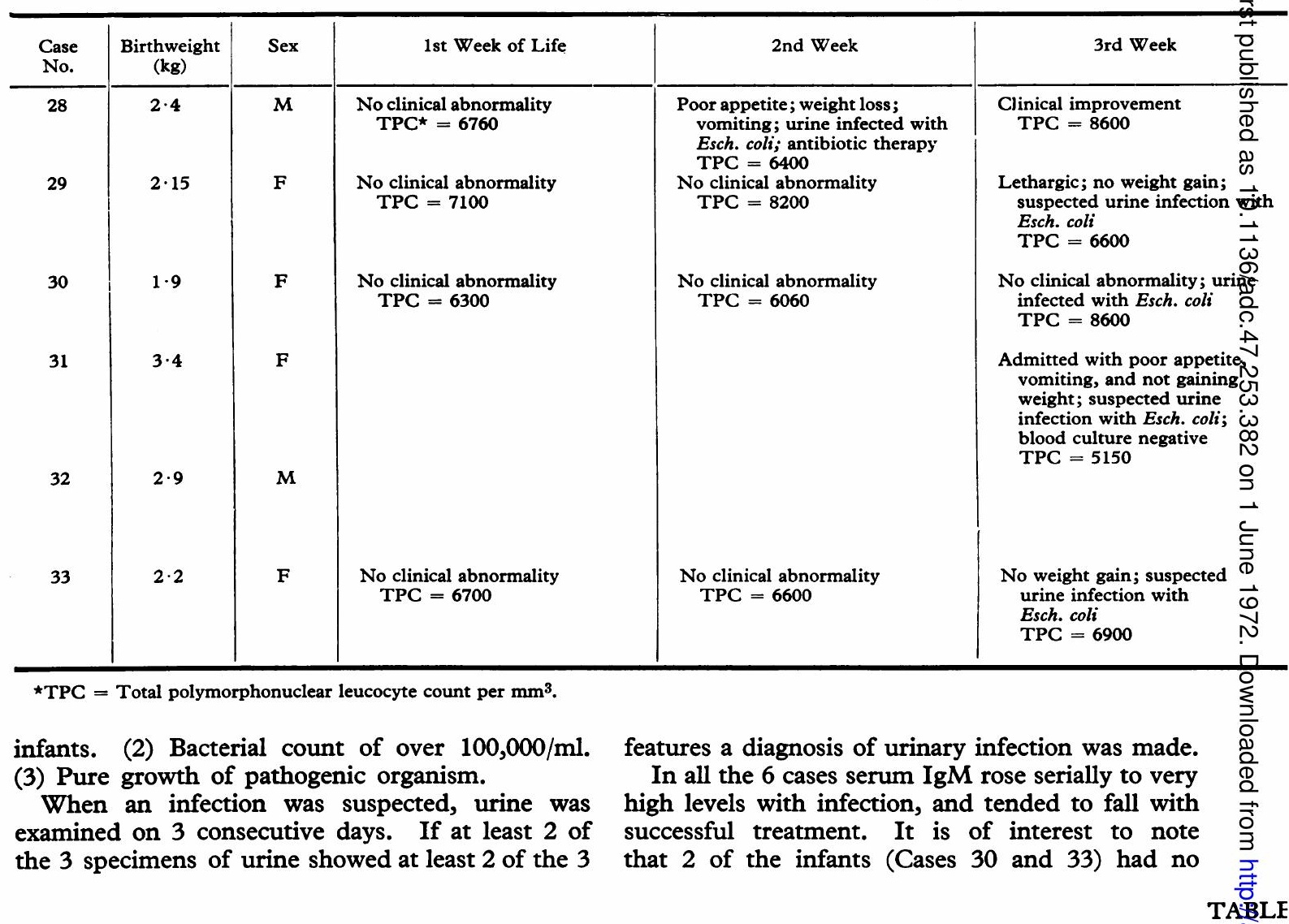

Summary of Relevant Clinical $\mathscr{\not}_{\text {atc }}$

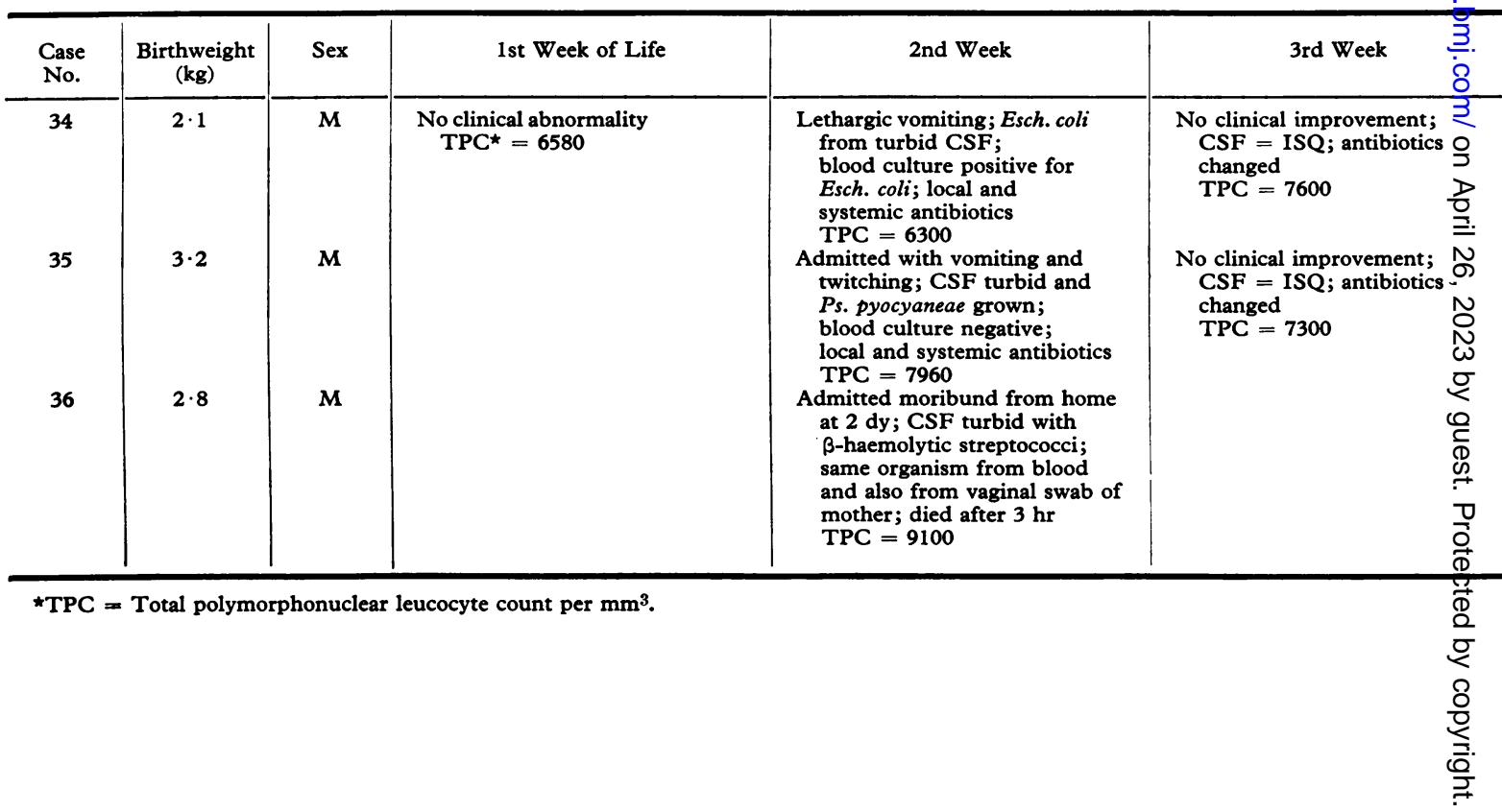


VI

\section{Neonates with Infected Urine}

\begin{tabular}{|c|c|c|c|}
\hline 4th Week & 5th Week & 6th Week & Follow-up \\
\hline $\begin{array}{l}\text { No clinical abnormality } \\
\text { TPC }=5900\end{array}$ & No clinical abnormality & No clinical abnormality & $\begin{array}{l}\text { Last IgM at } 10 \mathrm{wk} \text {; followed } \\
\text { for } 7 \mathrm{mth} \text {; no clinical } \\
\text { abnormality }\end{array}$ \\
\hline $\begin{array}{l}\text { Anorexic, lethargic; weight loss; } \\
\text { urine infected with Esch. coli; } \\
\text { blood culture positive for } \\
\text { Esch. coli; antibiotic therapy } \\
\text { TPC }=7660\end{array}$ & $\begin{array}{l}\text { Clinical improvement; } \\
\text { antibiotics continued } \\
\text { TPC }=5900\end{array}$ & No clinical abnormality & $\begin{array}{l}\text { Last IgM at } 7 \text { wk; followed for } \\
8 \mathrm{mth} \text {; no clinical abnormality } \\
\text { bifid pelvis on IVP }\end{array}$ \\
\hline $\begin{array}{l}\text { No clinical abnormality; urine } \\
\text { infected with Esch. coli; } \\
\text { antibiotic therapy } \\
\text { TPC }=6300\end{array}$ & $\begin{array}{l}\text { No clinical abnormality } \\
\text { TPC }=6100\end{array}$ & No clinical abnormality & $\begin{array}{l}\text { Last } \mathrm{IgM} \text { at } 12 \text { wk; followed for } \\
13 \mathrm{mth} \text {; no clinical abnormality }\end{array}$ \\
\hline $\begin{array}{l}\text { Symptoms persisting; urine } \\
\text { infected with Esch. coli; } \\
\text { antibiotic therapy } \\
\text { TPC }=6360\end{array}$ & $\begin{array}{l}\text { Clinical improvement; } \\
\text { antibiotic continued } \\
\text { TPC }=6000\end{array}$ & No clinical abnormality & $\begin{array}{l}\text { Last IgM at } 12 \text { wk; followed } \\
\text { for } 4 \mathrm{mth} \text {; no clinical } \\
\text { abnormality }\end{array}$ \\
\hline $\begin{array}{l}\text { Admitted with lethargy and loss } \\
\text { of weight; urine infected with } \\
\text { Esch. coli and Ps. pyocyanea; } \\
\text { antibiotic therapy } \\
\text { TPC }=7800\end{array}$ & $\begin{array}{l}\text { Clinical improvement; } \\
\text { antibiotic continued } \\
\text { TPC }=6900\end{array}$ & No clinical abnormality & $\begin{array}{l}\text { Last IgM at } 10 \text { wk; followed for } \\
8 \mathrm{mth} \text {; recurrence of urinary } \\
\text { infection at } 5 \mathrm{mth} \text {; ureteric } \\
\text { reflux on radiology }\end{array}$ \\
\hline $\begin{array}{l}\text { No weight gain; urine } \\
\text { infected with Esch. coli; } \\
\text { antibiotic therapy } \\
\text { TPC }=6300\end{array}$ & $\begin{array}{l}\text { No clinical abnormality } \\
\text { TPC }=6200\end{array}$ & No clinical abnormality & $\begin{array}{l}\text { Last IgM at } 12 \text { wk; followed } \\
\text { for } 8 \mathrm{mth} \text {; no clinical } \\
\text { abnormality }\end{array}$ \\
\hline
\end{tabular}

symptoms and, in fact, rising IgM levels led to repeated investigation and ultimately to the diagnosis.

\section{Neonates with bacterial meningitis (Fig. 11}

and Table VII). Serum IgM was markedly raised in all 3 cases. In the 2 surviving ones, serum IgM rose serially with infection. Here again serum IgM tended to fall with clinical and bacterological improvement.

VII

from 3 Neonates with Meningitis

\begin{tabular}{|c|c|c|c|}
\hline 4th Week & 5th Week & 6th Week & Follow-up \\
\hline $\begin{array}{l}\text { Slight clinical improvement; CSF } \\
\text { less turbid no organism; } \\
\text { antibiotics continued; } \\
\text { subdural taps normal } \\
\text { TPC }=7300\end{array}$ & $\begin{array}{l}\text { Clinical improvement } \\
\text { maintained; CSF returning } \\
\text { to normal; antibiotics } \\
\text { continued } \\
\text { TPC }=6960\end{array}$ & $\begin{array}{l}\text { Improvement maintained; } \\
\text { CSF normal; subdural } \\
\text { normal }\end{array}$ & $\begin{array}{l}\text { Last } \mathrm{IgM} \text { at } 10 \mathrm{wk} \text {; followed } \\
\text { for } 9 \mathrm{mth} \text {; no definite } \\
\text { clinical abnormality }\end{array}$ \\
\hline $\begin{array}{l}\text { No clinical improvement; } \\
\text { CSF = ISQ; subdural tap } \\
\text { normal; antibiotics continued } \\
\text { TPC }=8300\end{array}$ & $\begin{array}{l}\text { Some improvement in general } \\
\text { condition but appearance of } \\
\text { rt. hemiplegia; CSF less } \\
\text { turbid without organism; } \\
\text { subdural tap normal; } \\
\text { antibiotics continued } \\
\text { TPC }=6700\end{array}$ & $\begin{array}{l}\text { General improvement } \\
\text { maintained but rt. hemiplegia } \\
\text { established; CSF back to } \\
\text { normal; subdural normal }\end{array}$ & $\begin{array}{l}\text { Last IgM at } 9 \text { wk; followed for } \\
8 \mathrm{mth} \text {; left with rt. } \\
\text { hemiplegia }\end{array}$ \\
\hline
\end{tabular}




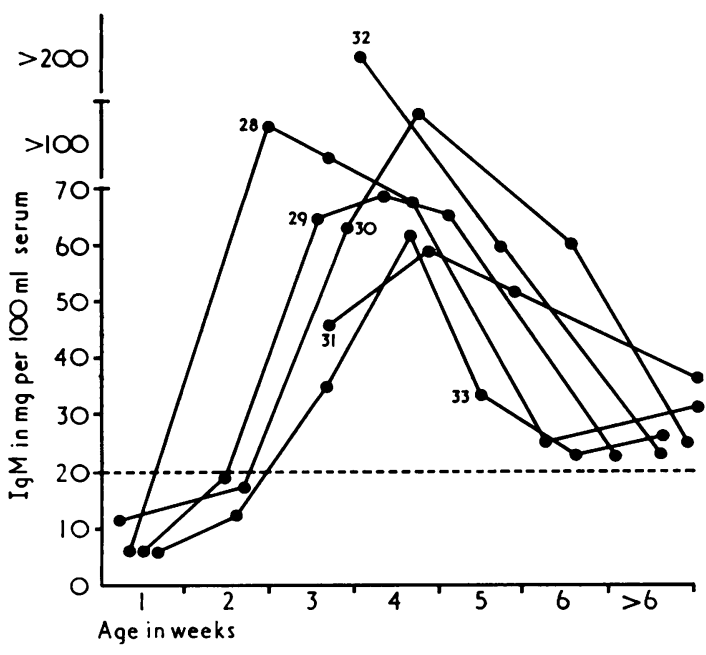

FIG. 10.-Serum IgM in the neonates with infected urine before and after treatment.

Neonates with probable infection (Fig. 12). During the period of observation a clinical diagnosis of infection was made in 19 cases but no pathogenic bacteria or viruses were isolated to establish the diagnosis. Behaviour of serum IgM was however found to be very similar to that observed in the neonates with established systemic infection.

\section{Discussion}

The human fetus has been found to be capable of producing immunoglobulins (Stiehm and Fuden-

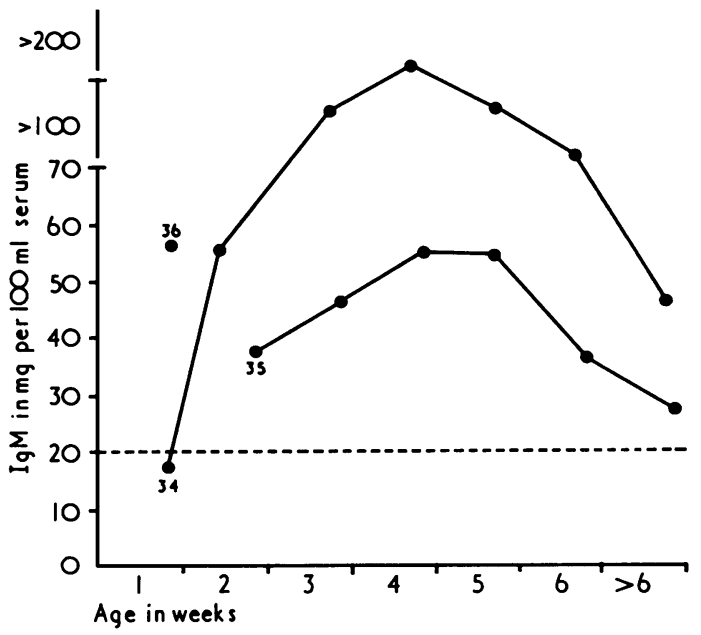

FIG. 11.-Serum IgM in the neonates with meningitis before and after treatment.

berg, 1966; Johansson and Berg, 1967; Rhodes et al., 1969). Synthesis of $\gamma$-globulin in the newborn infant begins in response to contact with infection or immunization. IgM is produced as the first humoral response to antigenic stimulation. Halflife of IgM is $\mathbf{5}$ days. It is generally agreed that the babies with infections commonly have raised serum IgM levels, but it has not been clearly shown how safely one can infer that a raised serum IgM level in the newborn signifies infection rather than some other form of stimulation of an immune response.

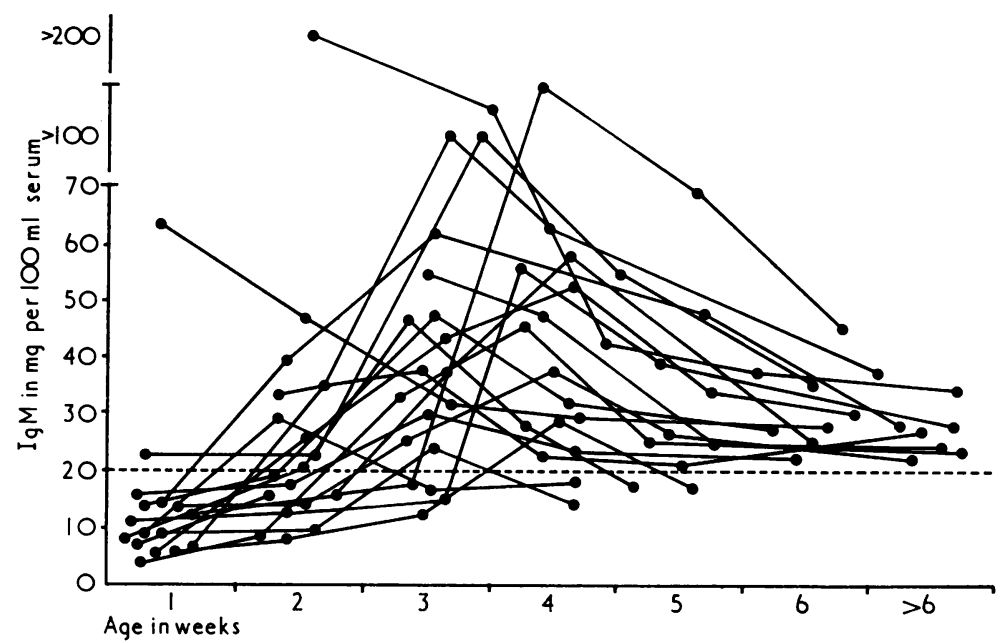

FIG. 12.-Serum IgM in the 19 neonates with probable infection before and after treatment. 
An increasing number of medical publications show varying levels of serum IgM in the neonates. Maturity, birthweight, and the environment in which the infant is nursed are some of the factors believed to influence the serum IgM levels in the early days of life (Stiehm and Fudenberg, 1966; Washburn, 1966; Johansson and Berg, 1967; Berg, 1968).

It was considered appropriate to establish the general pattern of the dynamics of serum IgM in the normal infants during the newborn period on the units connected with the study (Fig. 1-4). Serum IgM continued to rise after birth in both the NBW and LBW infants. The rate of rise was slower in the LBW infants as was observed by others (Norton, Kunz, and Pratt, 1952; Washburn, 1966; Berg, 1968). However, this does not imply that LBW babies are not as capable of producing IgM. It should be evident from the results of this study that LBW neonates have as good a capacity for early IgM synthesis as NBW babies.

The dynamics of IgM in the newborn infants had a characteristic pattern (hatched area in Fig. 1-4). Serum IgM levels serially rose after birth at variable rates. The most significant feature, however, was that the IgM curve did not show any drop.

On examining the dynamics of $\operatorname{IgM}$ in the babies who had infection the following 3 groups seemed to emerge.

Group I. Babies with local/superficial infection, without any significant local reaction or systemic symptoms. In these newborn infants the behaviour of IgM was not different from the 'normal'. It appears that the 'infection' was strictly localized and could not reach the immunologically competent cells. This explanation is perhaps too simple but not too unreasonable.

Group II. Babies with local/superficial infection, considerable local reaction, and systemic symptoms. Serum IgM in these cases rose to higher levels followed by a fall with eradication of infection. This dynamic pattern was characteristically different from the 'normal'.

Group III. Babies with internal/systemic infection. Serum IgM rose to considerably high levels with the establishment of infection. The rise was followed by a significant fall with clinical and bacteriological response to treatment.

It would be reasonable to assume that an 'antigenic stimulus' for the synthesis of IgM appeared with infection. The rise in serum IgM was detectable within 48 hours of the appearance of the symptoms. This 'antigenicity' persisted with the 'infectivity' and serum IgM continued to rise till the infection was controlled. Eradication of infection corresponded to the disappearance of the 'antigenic stimulus' and the IgM tended to fall by the end of the week after the control of infection.

In the 19 cases in which a clinical diagnosis of infection (6 respiratory and 13 gastrointestinal) was made but no organism was isolated, the behaviour of serum IgM (Fig. 12) was similar to that observed in Group III cases. However, in the 85 cases with 11 different noninfective conditions the dynamics of IgM was not like that seen in Groups II and III.

The rate of formation of serum IgM in the neonates with infection was apparently independent of age, birthweight, the type of organism and its pathogenicity. Instead, the site of infection was found to affect the dynamics of IgM.

In conclusion, a rise in serum IgM with the onset of an illness followed by a fall with an effective treatment may be considered indicative of an infective aetiology of the illness.

I thank Dr. W. Dickson for help and encouragement, and am indebted to the staff of the Paediatric, Nursing, and Pathology Departments for co-operation.

\section{REFERENCES}

Alford, C. A. (1969). Subclinical congenital infections. (3rd International Congress, Congenital Malformations, The Hague, September 7-13, 1969.) Diagnostica, 4, No. 2.

Alford, C. A., Schaefer, J., Blankenship, W. J., Straumfjord, J. V. and Cassady, G. (1967). A correlative, immunologic, microbiologic and clinical approach to the diagnosis of acute and chronic infections in newborn infants. New England fournal of Medicine, 277, 437.

Berg, T. (1968). Immunoglobulin levels in infants with low birth weights. Acta Paediatrica Scandinavica, 57, 369.

Johansson, S. G. O., and Berg, T. (1967). Immunoglobulin levels in healthy children. Acta Paediatrica Scandinavica, 56, 572.

Jones, D. M., and Tobin, B. M. (1969). Umbilical-cord IgM and amniotic infection. (Letter to the Editor.) Lancet, 1, 372.

Mancini, G., Carbonara, A. O., and Heremans, J. F. (1965). Immunochemical quantitations of antigens by single radial immunodiffusion. Immunochemistry, 2, 235.

Norton, P. M., Kunz, H., and Pratt, E. L. (1952). Electrophoretic analysis of serum proteins in premature infants. Pediatrics, $10,527$.

Rhodes, K., Markham, R. L., Maxwell, P. M., and Monk-Jones, M. E. (1969). Immunoglobulins and the X-chromosomes. British Medical fournal, 3, 439.

Stiehm, E. R., Ammann, A. J., and Cherry, J. D. (1966). Elevated cord macroglobulins in the diagnosis of intrauterine infections. New England Fournal of Medicine, 275, 971.

Stiehm, E. R., and Fudenberg, H. H. (1966). Serum levels of immunoglobulins in health and disease: a survey. Pediatrics, 37, 715.

Washburn, T. C. (1966). A longitudinal study of serum immunoglobulins in newborn premature infants. Bulletin of the fohns Hopkins Hospital, 118, 40.

Correspondence to Dr. S. A. Haider, Ministry of Health, P.O. Box 393, Muscat, Oman. 